\title{
Genotypic variation of seed yield and architectural traits in dwarf autumn-sown white lupin
}

\author{
N Harzic ${ }^{1 *}$, C Huyghe 1, J Papineau 1, C Billot 2, R Esnault 3, C Deroo ${ }^{4}$ \\ 1 Station d'amélioration des plantes fourragères, Inra, F-86600 Lusignan; \\ 2 Service de recherches intégrées végétales, Inra, domaine de Gotheron, F-26320 Saint-Marcel-Lès-Valence; \\ 3 Inra, domaine de la Motte, BP 29, F-35650 Le Rheu; \\ 4 GIE Lupsem, ZA La Georginière, F-86600 Lusignan, France
}

(Received 3 November 1995; accepted 29 April 1996)

\begin{abstract}
Summary - Dwarfism is a way of preventing excessive vegetative development in the indeterminate autumn-sown white lupin. Thirty-five dwarf genotypes of autumn-sown white lupin were evaluated in France in five different environments. The genotypes were XA100, the dwarf progenitor, and thirty-four other genotypes selected in the progenies of crosses between XA100 and tall genotypes. Seed yield, mean seed weight and number of seeds per square metre showed large genetic variations and high heritability. The dwarf population yielded an average of $37.8 \mathrm{q} / \mathrm{ha}$ and the dwarf progenitor yielded an average of 34.9 q/ha. The genotype*environment interaction was not significant in seed yield when tested throughout the five environments. The first-order branches contributed to the major part of the total seed yield. Traits of plant architecture were recorded in four environments. The flowering date, and number of leaves showed large genetic variations. Internode length varied among genotypes. The genetic variation of the number of branches was low. Few relationships between seed yield and architectural traits were observed. The genetic correlations between the mainstem or branch length and seed yield were positive. The flowering date and seed yield were not related.
\end{abstract}

white lupin / dwarfism / seed yield / genetic variation

Résumé - Variabilité génétique du rendement en graines et de l'architecture chez le lupin blanc d'hiver de type nain. Le nanisme est un moyen de réduire le développement végétatif exubérant du lupin blanc d'hiver. Trentecinq génotypes de lupin blanc d'hiver de type nain ont été évalués dans cinq milieux en France. Ces trente-cinq génotypes sont XA100, le géniteur de nanisme et trente-quatre autres génotypes nains sélectionnés dans la descendance de croisements entre XA100 et des génotypes non-nains. Le rendement en grains, le poids de 1000 grains et le nombre de grains par mètre carré présentent une large variabilité génétique et une forte héritabilité. Le rendement moyen de la population naine est égal à 37,8 q/ha et celui du géniteur de nanisme à 34,9 q/ha. Sur les cinq milieux, l'interaction génotype*milieu n'est pas significative pour le rendement en grains. Les ramifications primaires constituent le niveau de ramification ayant la plus forte contribution au rendement. Des caractères d'architecture ont été notés dans quatre lieux. La date de floraison et le nombre de feuilles sont génétiquement très variables. La longueur des entre-nœuds varie selon les génotypes. Peu de relations ont été observées entre le rendement en grains et les caractères d'architecture. La corrélation génétique entre la longueur des tiges, tige principale ou ramifications primaires, et le rendement est positive. La date de floraison n'est pas corrélée au rendement.

lupin blanc / nanisme / rendement en grains / variabilité génétique 


\section{INTRODUCTION}

Most of the white lupin cultivars presently available (Lupinus albus L) are spring-sown. However, the seed yield and yield stability of autumn-sown white lupins are expected to be better than those of spring-sown crops as already reported for pea (Étévé and Derieux, 1982). Frost tolerance is considered a major breeding objective for the autumn-sown white lupin (Huyghe and Papineau, 1990). The first autumn-sown cultivar with high frost tollerance, Lunoble, was released in 1989. It is late flowering and characterized by a vigorous indeterminate growth habit. It has a high seed yield potential but owing to its strong vegetative development, its yield has proved to be unstable (Huyghe et al, 1994b). Dwarfism is a way of reducing vegetative development and of improving lodging resistance. It modifies the plant architecture by a reduction in the stem length. The comparison between the tall and dwarf lines of six near-isogenic lines for the dwarf character, showed that dwarfism reduced the mainstem height by $41 \%$ and the branch length by $22 \%$ linked with a decrease of the internode length and a lower internode number (minus 1 for the mainstem and minus 0.5 for the first-order branch). The number of primary branches was also slightly decreased (minus 0.25) (Harzic and Huyghe, 1996). The agronomic potential of the dwarf progenitor XA100 has been compared with that of Lunoble. This study showed that the seed yield of XA100 was not different from that of Lunoble but its harvest index was higher (Harzic et al, 1996). Dwarfism allowed a greater allocation of dry matter in pods and a subsequent high seed yield.

The production of each pod order to total seed yield was different for XA100 and Lunoble, with XA100 producing more on the third and fourth branch orders. The dwarf character was introduced into a range of genetic backgrounds in autumn-sown material by crossing the dwarf progenitor with tall genotypes, and by a selection of dwarf lines in the progenies. The seed yield potential of the dwarf population and its genetic variation must therefore be evaluated for the future breeding of dwarf lupin lines. Information on the relative merits of architectural traits to seed yield must be available before defining the indirect selection criteria of the seed yield of the dwarf lupin. An assessment was made on the effect of genotypes and environment on seed yield and architectural traits, as well as an investigation into the relationships between seed yield and plant architecture.

\section{MATERIAL AND METHODS}

$X A 100$, the dwarf progenitor, was selected from the progeny of the tall population LA100 after mutagenesis. Thirty-four dwarf genotypes were selected in the progenies of crosses between the dwarf progenitor XA100 and tall genotypes (table I), and chosen to cover the range of variation observed in seed yield and plant architecture among autumn-sown dwarf lupins (Harzic, 1992). They were also chosen to represent the variation available among crosses. These were F6 lines except for GE154 and GE155 which were F5 lines. GE154 and GE155 were indeterminate genotypes selected in the progeny between XA100 and a determinate line. XA100 was also included in the experimental design. The genotypes GE146, GE154 and GE155 were only grown for one year (1993/1994), all the other genotypes were grown over a period of two years (1992/1993 and 1993/1994). No experiments were made with the tall parents, hence no comparison was made between the population and its tall parents. The planting sites were Lusignan (INRA, Vienne, $46^{\circ} 30^{\prime} \mathrm{N}$ latitude) in $1992 / 1993$ and in 1993/1994 and Gotheron (INRA, Drôme, 4450' N latitude), Rennes (INRA, Ille-et-Vilaine, 48 $10^{\prime} \mathrm{N}$ latitude) and Cossé-Le-Vivien (GIE Lupsem, Mayenne, $47^{\circ} 50^{\prime}$ $N$ latitude) in 1993/1994. The autumn was warm in Lusignan 1993 (table II). In Gotheron, the summer was warmer and the rainfall higher than in the other environments. The summer was drier in Rennes than in the other environments. The sowing dates were 13 October 1992 and 19 October 1993 in Lusignan, 13 October 1993 in Gotheron, 27 October 1993 in Rennes and 28 October 1993 in Cossé-Le-Vivien. The sowing density was $25 \mathrm{seeds} / \mathrm{m}^{2}$. On each site, the experiment was carried out in a randomized block design with three replications. The plot size was $3 \mathrm{~m}$ long with five rows $0.5 \mathrm{~m}$ apart in Lusignan, $3 \mathrm{~m}$ long with three rows $0.5 \mathrm{~m}$ apart in Gotheron, $9 \mathrm{~m}$ long with three rows $0.45 \mathrm{~m}$ apart in Cossé-Le-Vivien and $6 \mathrm{~m}$ long with three rows $0.45 \mathrm{~m}$ apart in Rennes.

In each site, seed yield (at 15\% moisture content) was measured on the whole plot. Mean seed weight (MSW) was evaluated on a sample of 250 seeds and the number of seeds $/ \mathrm{m}^{2}$ was also calculated. The date of flowering was recorded as the day on which $50 \%$ of the plants had at least one open flower on the mainstem. Flowering dates are presented as degree-days $\left({ }^{\circ} \mathrm{Cd}\right)$ above $3{ }^{\circ} \mathrm{C}$ from sowing.

Except in Cossé-Le-Vivien, the architecture of the plant was described on ten adjacent plants per plot at full vegetative development (fig 1). The height of the mainstem was measured between the cotyledon position and the bottom of the mainstem inflorescence. The number of first-order branches was counted. The number of leaves and the length of the second firstorder branch (numbering from the uppermost branch) were measured. The average internode length of this branch was calculated as the ratio between branch length and number of leaves. The number of leaves on the second first-order branch provides a reliable estimate of the mean number of leaves for all the branch- 
Table I. Genetic origin of the 35 dwarf lupin genotypes.

Cross $^{\mathrm{a}}$

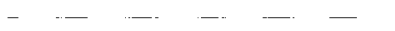

XA100* ITA29

XA100* ITA9

ITA9*XA100

ITA30*XA100

XA100*ITA31

ITA31*XA100

ITA34*XA100

ITA41*XA100

XA100*ITA56

ITA56*XA100

XA100*ITA62

ITA62*XA100

cv Lunoble ${ }^{\star} X A 100$

XA100*(LA300*LA195)
Genotypes

XA100

GE14, GE15, GE18, GE20, GE22

GE33, GE35, GE36

GE38, GE40, GE41, GE45, GE47, GE49

GE55, GE59

GE60, GE61, GE64

GE72, GE75

GE78, GE82

GE97, GE99

GE105, GE106

GE113, GE117

GE118

GE130

GE146

GE154, GE155

a ITA9, ITA29, ITA30, ITA31, ITA34, ITA56, ITA62, are Italian ecotypes, LA300 is a determinate spring genotype, and LA195 is an Azoren ecotype.

Table II. Monthly average minimum $\left(T_{\min }\right)$ and maximum $\left(T_{\max }\right)$ temperatures $\left({ }^{\circ} \mathrm{Cd}\right)$ and rainfall $(\mathrm{mm})$ in Lusignan in 1992/1993 and 1993/1994, Gotheron, Rennes and Cossé-Le-Vivien.

Oct Nov Dec Jan Feb Mar Apr May Jun Jul Aug Sep

Lusignan 1992/1993

$\mathrm{T}_{\min }$

Rainfall

$\begin{array}{rrrrrrr}6.5 & 7.3 & 3.5 & 4.8 & 0.0 & 3.1 & 6.2 \\ 13.2 & 13.6 & 8.4 & 10.6 & 8.9 & 13.3 & 14.9 \\ 113.5 & 128.0 & 101.0 & 37.5 & 11.0 & 9.5 & 106.0\end{array}$

$\begin{array}{rr}9.5 & 12.6 \\ 18.9 & 23.3\end{array}$

$84.5 \quad 120.5$

$\begin{array}{lll}12.5 & 12.6 & 10.5\end{array}$

$24.0 \quad 25.1 \quad 19.2$

$\begin{array}{lll}27.5 & 32.5 & 137.0\end{array}$

Lusignan 1993/1994

$$
\begin{aligned}
& T_{\min } \\
& T_{\max } \\
& \text { Rainfall }
\end{aligned}
$$

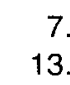

116.0
$7.6 \quad 1.6$

$$
8.6
$$

25.0 $\begin{array}{rrrrr}4.8 & 4.0 & 4.0 & 5.8 & 5.2\end{array}$

$9.6 \quad 8.6$

$154.5 \quad 151.5$
$10.7 \quad 14.1 \quad 13.8$

$91.0 \quad 36.5 \quad 74.0$
$9.2 \quad 11$.

19.723.

$55.5 \quad 83.0$ $\begin{array}{lll}15.5 & 14.7 & 11.0\end{array}$

$28.0 \quad 26.0 \quad 18.9$

$43.0 \quad 70.5 \quad 175.5$

Gotheron 1993/1994

$$
\begin{aligned}
& \mathrm{T}_{\text {min }} \\
& \mathrm{T}_{\text {max }} \\
& \text { Rainfall }
\end{aligned}
$$

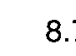

8.7
15.3

292.5

$\begin{array}{rrrrrr}2.9 & 9.1 & 1.9 & 3.3 & 6.3 & 10.8 \\ 8.1 & 3.3 & 7.7 & 9.9 & 17.0 & 21.5 \\ 41.0 & 36.5 & 162.0 & 41.5 & 17.5 & 95.0\end{array}$

13.9

25.031

\begin{tabular}{|c|c|c|c|c|c|c|c|c|c|c|c|c|}
\hline$T_{\min }$ & 7.1 & 1.5 & 4.8 & 4.4 & 3.6 & 5.9 & 8.9 & 10.7 & 13.7 & 13.5 & 13.5 & 10.8 \\
\hline $\mathrm{T}_{\max }$ & 13.6 & 8.9 & 11.0 & 10.2 & 10.6 & 13.8 & 18.1 & 23.3 & 26.5 & 24.8 & 24.8 & 18.9 \\
\hline Rainfall & 99.5 & 29.5 & 76.0 & 107.0 & 95.5 & 29.5 & 108.5 & 29.5 & 60.5 & 32.5 & 32.5 & 119.5 \\
\hline
\end{tabular}

67.551 .0 $\begin{array}{lll}16.6 & 16.6 & 12.5\end{array}$

\begin{tabular}{|c|c|c|c|c|c|c|c|c|c|c|c|}
\hline $\mathrm{T}_{\min }$ & 6.7 & 1.2 & 4.5 & 3.8 & 2.8 & 5.2 & 8.5 & 11.0 & 14.5 & 13.9 & 13.9 \\
\hline $\mathrm{T}_{\max }$ & 13.5 & 8.4 & 10.3 & 9.6 & 10.4 & 13.8 & 19.0 & 23.7 & 27.6 & 25.4 & 25.4 \\
\hline Rainfall & 131.7 & 28.2 & 95.2 & 79.3 & 106.4 & 29.7 & 116.6 & 35.2 & 41.9 & 67.5 & 67.5 \\
\hline
\end{tabular}
$\begin{array}{lll}29.4 & 29.4 \quad 20.8\end{array}$ $38.0 \quad 38.0 \quad 269.5$

\section{Rennes 1993/1994}

Cossé-Le-Vivien 1993/1994 


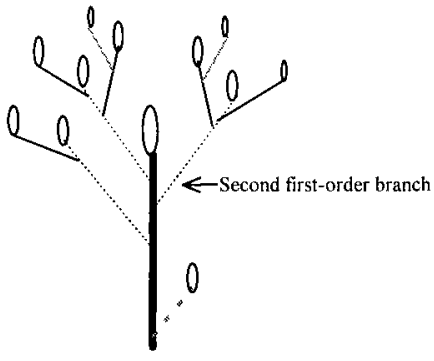

Fig 1. Branching structure in $L$ albus showing the mainstem and the various orders of branches.

es (Huyghe et al, 1994a). The total number of leaves on the first-order branches was calculated from the number of first-order branches and the number of leaves on the second first-order branch.

For all the genotypes in Lusignan, and for 13 genotypes in Gotheron, the seed yield of the different branch orders was measured on ten adjacent plants per plot. The number of seeds in each branch order was measured and the MSW was calculated. The contribution of each branch order to the seed yield was calculated and then used to estimate the yield per order for the whole plot.

The analyses of variance were performed with the type III sum of squares of the GLM procedure of the SAS Institute (1988). The design was analysed with the effects of genotype, environment, block nested within environment and interaction genotype ${ }^{\star}$ environment. The environment and block effects were considered as fixed effects. Each combination of sowing date* site was considered as one environment. Adjusted means were calculated. From the analysis of variance, estimates of the genetic variance $\left(\sigma^{2} \mathrm{~g}\right)$ and covariance, the error variance $\left(\sigma^{2} r\right)$ and the genotype ${ }^{\star}$ environment variance $\left(\sigma^{2}\right.$ g.e $)$ were obtained. The variance were compared with the $F$ test. Broad sense heritabilities $\left(h^{2}\right)$ were calculated as:

$$
h^{2}=\frac{\sigma^{2} g}{\sigma^{2} g+\frac{1}{l} \sigma^{2} g \cdot e+\frac{1}{n l} \sigma^{2} r}
$$

I: number of environments, $n$ : number of blocks

Standard errors of genetic correlations were calculated according to Becker (1975).

\section{RESULTS}

\section{Genetic and phenotypic variation for seed yield, mean seed weight and number of seeds $/ m^{2}$}

For each of these three characters, the environmental and genotype effects were significant

Table III. Mean squares from analysis of variance, genetic variance $\left(\sigma^{2} \mathrm{~g}\right)$ genotype*environment variance $\left(\sigma^{2} \mathrm{ge}\right)$ and broad sense heritability $\left(\mathrm{h}^{2}\right)$ of seed yield, MSW and seeds $/ \mathrm{m}^{2}$ measured on dwarf autumn-sown white lupin.

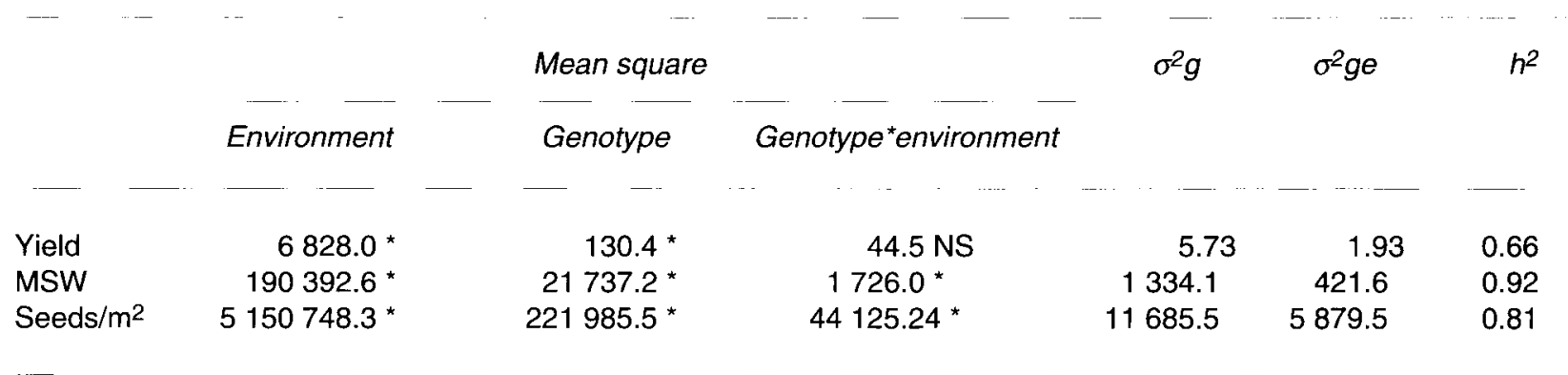

\footnotetext{
* Significant at $P<0.001$, NS non significant
} 
Table IV. Range of variation of seed yield and of seed yield components of dwarf autumn-sown white lupin, and environmental mean in Lusignan (Lus), Gotheron, Rennes and Cossé-Le-Vivien (Cossé).

Mean SD Variation among genotypes

Mini Maxi XA100 Lus 1993 Lus 1994 Gotheron Rennes Cossé

$\begin{array}{lcccccccccc}\text { Seed yield }(\mathrm{q} / \mathrm{ha}) & 37.8 & 3.10 & 28.1 & 45.7 & 34.9 & 49.6 & 44.4 & 31.0 & 29.4 & 35.3 \\ \mathrm{MSW}(\mathrm{g}) & 0.372 & 0.040 & 0.289 & 0.462 & 0.328 & 0.382 & 0.345 & 0.317 & 0.353 & 0.426 \\ \text { Seeds } / \mathrm{m}^{2} & 1013.8 & 124.63 & 812.2 & 1217.5 & 1064.4 & 1272.0 & 1277.5 & 969.6 & 846.6 & 825.6\end{array}$

SD: standard deviation; mini: minimum; maxi: maximum.

(table III). The genotype ${ }^{\star}$ environment interaction was not significant for seed yield, but was significant for MSW and number of seeds $/ \mathrm{m}^{2}$. For MSW and number of seeds $/ \mathrm{m}^{2}$, the genotypic effect was significant when tested against the genotype*environment effect. The environmental effect was large compared to the other effects in the analysis of variance. Broad-sense heritability was lower for seed yield than for its components (table III). Table IV shows the mean value of seed yield and of its components, and the range of variation for these characters. The dwarf geno- types yielded an average of $37.8 \mathrm{q} / \mathrm{ha}$ and the dwarf progenitor XA100 $34.9 \mathrm{q} / \mathrm{ha}$. Two genotypes (GE36 and GE97) yielded more than 60 $q /$ ha in Lusignan in 1993. Only four genotypes yielded on average less than XA100 $(P<0,05)$. Seed yield was higher $(P<0.01)$ in Lusignan in 1993 and in 1994. MSW was higher in Cossé-leVivien $(P<0.01)$ (table IV).

MSW of each genotype in each environment was plotted against the number of seeds $/ \mathrm{m}^{2}$ (fig 2). The lines on the graph are curves of constant yield. The figure shows that yield variation
Fig 2. Relationship between the number of seeds $/ \mathrm{m}^{2}$ and the MSW for the dwarf lupin genotypes in five environments (匹 Lusignan 1993, - Lusignan 1994, O Gotheron, $\triangle$ Rennes, CosséLe-Vivien).

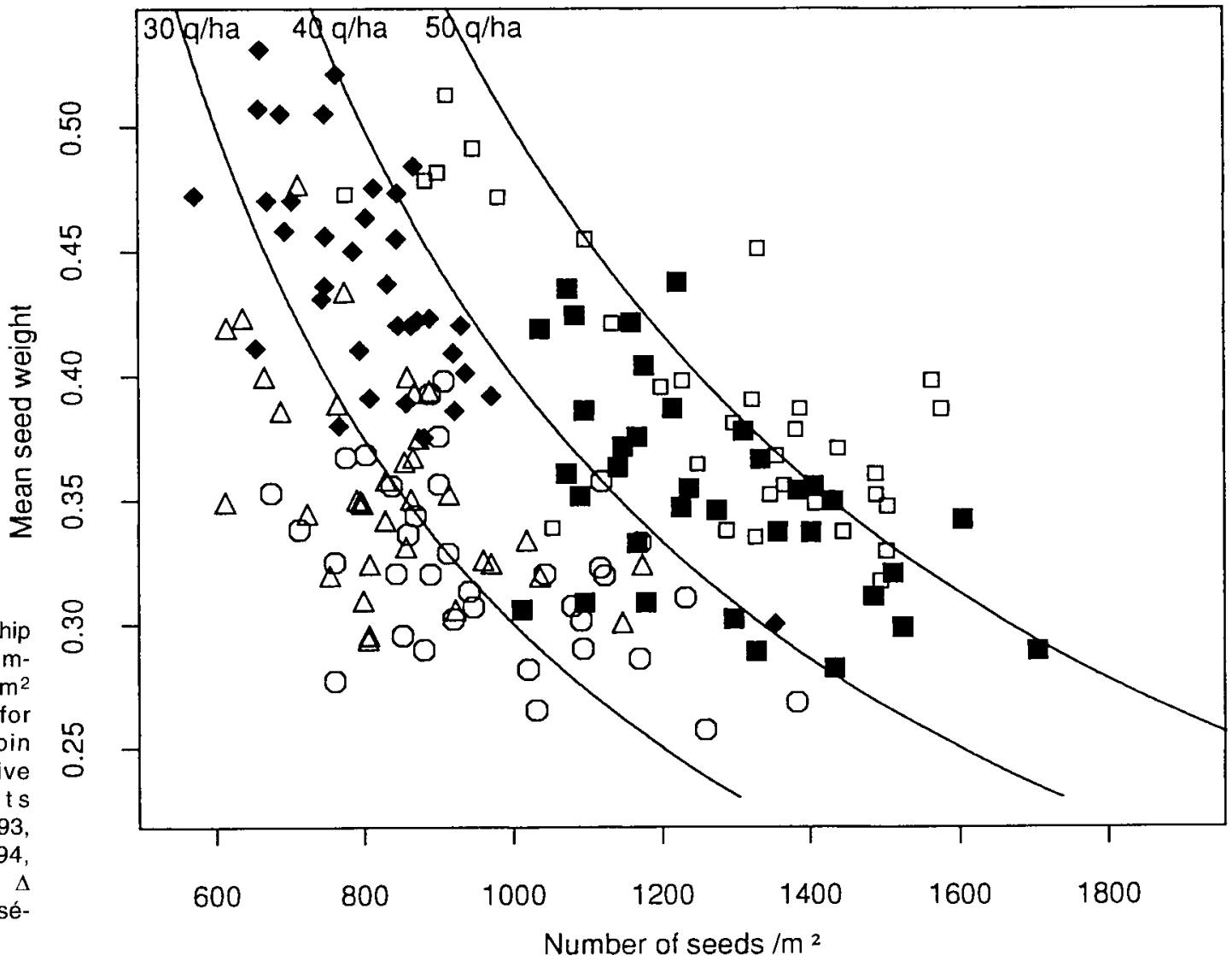




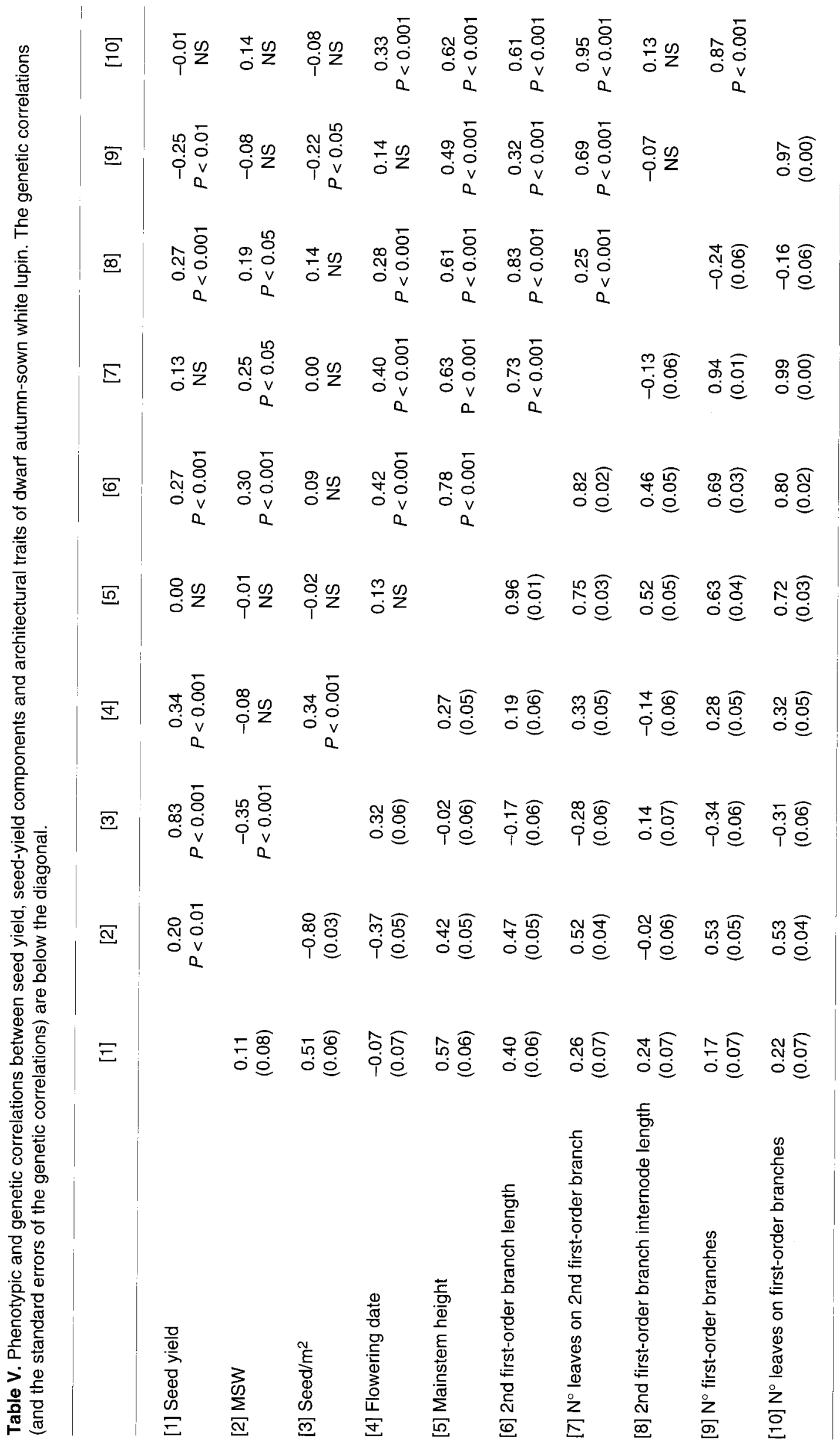


Fig 3. Distribution of the seed yield on the different branch orders for 13 genotypes grown in Lusignan in 1993 and in 1994 and in Gotheron in 1994.

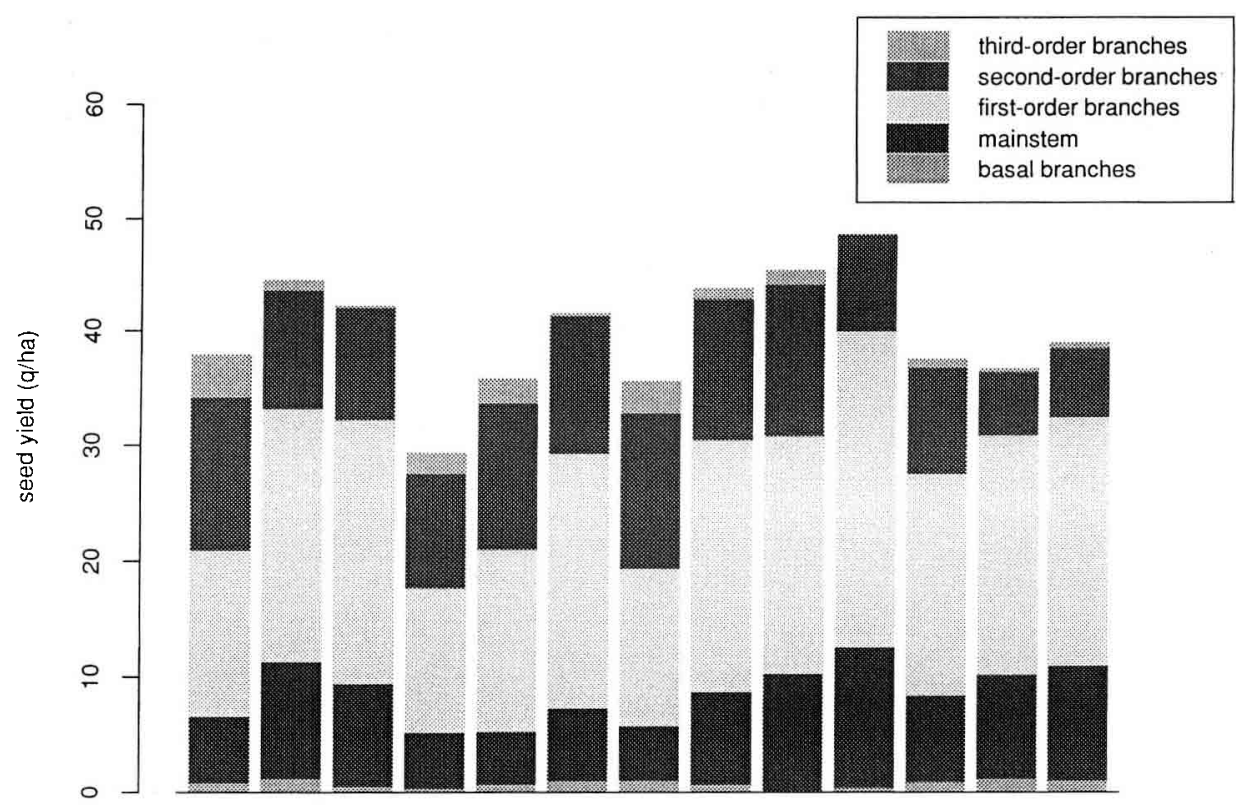

GE15 GE36 GE49 GE55 GE59 GE60 GE64 GE78 GE82 GE97 XA100GE106GE113 was due to a large variation in the number of seeds $/ \mathrm{m}^{2}$ and in a lesser extent to a variation in MSW. The low seed yield in Cossé-le-Vivien was the combination of a low number of seeds $/ \mathrm{m}^{2}$ (826) and a high MSW $(0.436 \mathrm{~g})$. The phenotypic correlation between seed yield and number of seeds $/ \mathrm{m}^{2}$ was high $(r=0.83 P<0.001$ ) (table $\mathrm{V}$ ). Both the phenotypic and the genetic correlations between MSW and seed yield were low, but the phenotypic correlation was significant $(r=0.20$ $P<0.01)$.

\section{Distribution of seed yield on the branch orders}

Seed yield per branch order varied significantly among genotypes and environments. Figure 3 shows the distribution of the seed yield of the 13 genotypes studied in three environments. The number of productive branch orders did not vary significantly among genotypes. Development of productive basal branches was more important in Gotheron. The effect of branch order on seed yield was significant. On average, seed yield was highest on first-order branches (21.5 q/ha) which contributed $49 \%$ of total seed yield. The yield of the mainstem ( $8.5 \mathrm{q} / \mathrm{ha}$ and $20 \%$ of the total seed yield) was also on average lower than that of the second-order branches (11.5 q/ha). Total seed yield was positively correlated to mainstem seed yield $(r=0.54 P<0.0001)$ and to yield on the first-order branches $(r=0.75 P<0.0001)$. The seed yields of the second- and third-order branches were negatively correlated to total seed yield. The basal branches had a low contribution to the seed yield $(1.4 \%)$ and their seed yield was not correlated to total seed yield.

The yield components per branch order, ie, MSW and number of seeds $/ \mathrm{m}^{2}$, varied significantly among branch orders. The genetic effect was not significant for MSW of third-order and basal branches, or for the number of seeds $/ \mathrm{m}^{2}$ on the basal branches. MSW was higher $(P<0.05)$ on the first-order branches $(0.391 \mathrm{~g})$ and on the mainstem $(0.379 \mathrm{~g})$. MSW of the different branch orders were significantly correlated to each other.

\section{Genetic and phenotypic variation of the plant architecture}

Effects of the environment and of the genotype on plant architecture and the genotype ${ }^{\star}$ environment interaction were significant $(P<0.05)$. The environmental effect was large compared to the other effects ( 17 to $71 \%$ of the total variation). The genetic effect was significant when tested against the genotype ${ }^{\star}$ environment effect. The genotype ${ }^{*}$ environment variances were significantly lower than the genetic variances. The characters of plant architecture were recorded in four environments, although the seed yield was investigated in five environments. When tested over four environments, the genotype environment interaction was significant for both architectural traits and seed yield. 


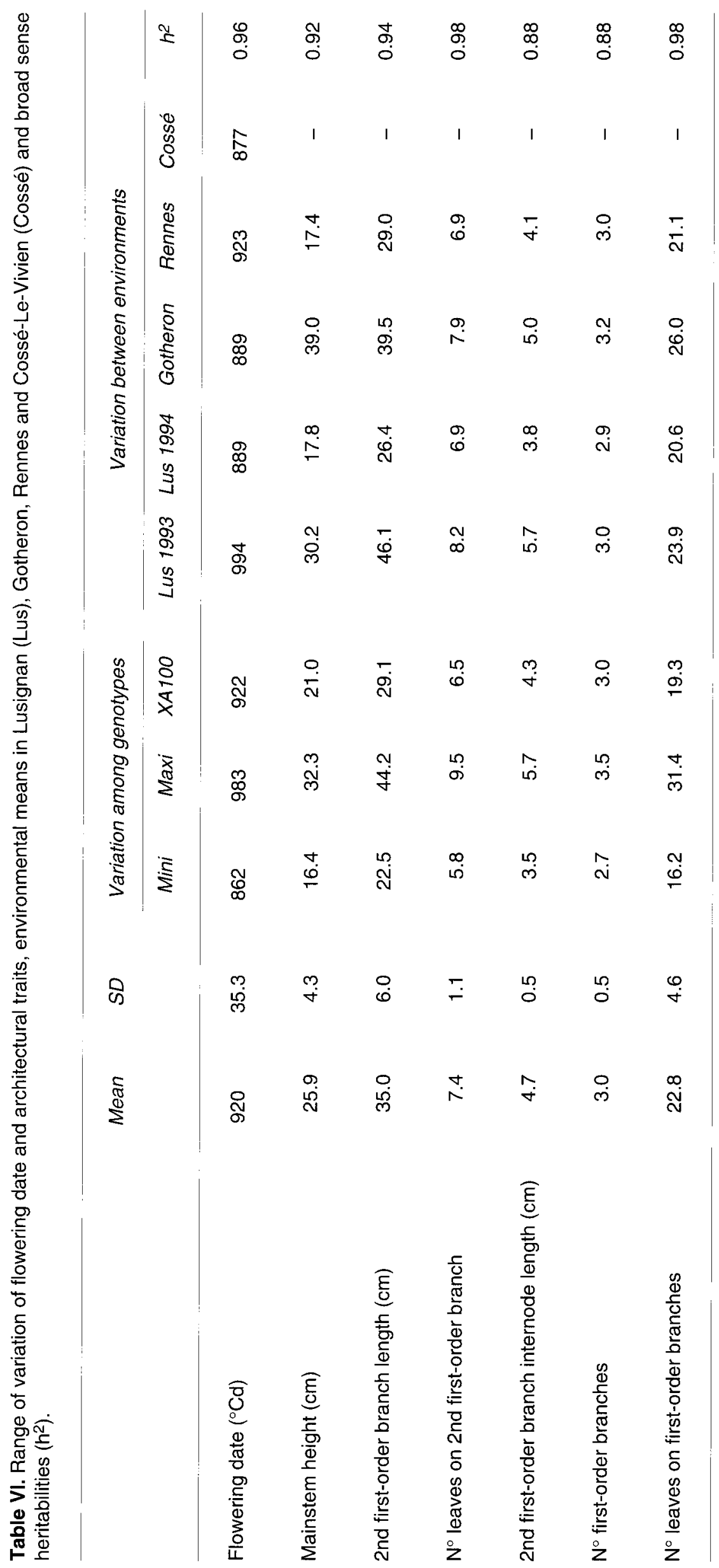


The broad sense heritabilities of the architectural characters were high (table VI), being at least equal to 0.88 for the number of first-order branches and second first-order branch internode length.

The average flowering date was $920^{\circ} \mathrm{Cd}$ (table $\mathrm{VI}$ ). The mean flowering date of the earliest genotype and that of the latest one were separated by $121{ }^{\circ} \mathrm{Cd}$. The genetic variation was high especially for branch length and the number of leaves. GE154 was the shortest and the earliest genotype. Its mainstem was $16.4 \mathrm{~cm}$ high and its second first-order branch was $22.5 \mathrm{~cm}$ long. The latest genotype (GE113) had the highest mainstem $(32.3 \mathrm{~cm})$ and the longest branches $(44.2 \mathrm{~cm})$. The stem length differences between genotypes were due to both the variation of the leaf number (ie, internodes) and the variation in internode length. GE154 had the shortest internodes $(3.5 \mathrm{~cm})$ and GE14 the longest ones $(5.7 \mathrm{~cm})$. The difference in the number of firstorder branches was very low, being inferior to 1 .

The plants were less developed $(P<0.05)$ in Lusignan in 1994 than in the other environments. This was due to a late planting date and cool weather during the first two months of the growth cycle which induced an early vernalization and a subsequent reduction of vegetative development.

The phenotypic and genetic correlations between the characters of plant architecture are reported in table $\mathrm{V}$. It appeared that the late genotypes were taller and produced more branches and leaves. The genetic correlation between the flowering date and first-order branch internode length was negative $(-0.14)$. The mainstem and branch length as well as the first-order branch internode length were positively correlated both at the phenotypic and genetic levels. The number of first-order branches was positively linked with the architectural traits, except for the first-order internode length.

\section{Seed yield and architecture}

In five environments the phenotypic correlation between flowering date and seed yield was 0.34 $(P<0.001)$ (table $V)$, whereas the genetic one was -0.07 . In four environments the genetic correlation between mainstem height and seed yield was 0.57 . The phenotypic correlation was nil. The genetic correlation between second firstorder branch length and seed yield was 0.40 . None of the other architectural characters showed a high genetic correlation with the seed yield. The genetic correlation between mainstem height and number of seeds $/ \mathrm{m}^{2}$ was -0.02 . MSW showed high genetic correlations with stem lengths, number of branches and number of leaves.

\section{DISCUSSION}

Despite the genotypes having been chosen to cover a wide variation among the dwarf population for most of the characters, the average seed yield of the genotypes under study was higher than that of the dwarf progenitor XA100. It has been demonstrated that XA100 seed yield was similar to that of the tall indeterminate cultivar Lunoble (Harzic et al, 1995). These results showed the large seed-yield potential of the dwarf genotypes selected from the progenies of crosses between tall indeterminate genotypes and XA100, the dwarf line. Seed-yield heritability (0.66) was higher than those calculated for other indeterminate white lupin populations [0.57 (Green et al, 1977) or 0.44 (Le Sech and Huyghe, 1991)] but lower than that calculated for the determinate population [0.78 (Julier et al, 1995)]. Determinate structure improved seed yield stability (Julier et al, 1993), which contributed to reduce the residual variance of seed yield and consequently to improve heritability. Mean seed yield and the large range of variation, as well as the heritability showed that progress in seed yield can be achieved in the dwarf population. The genotype environment interaction for the seed yield was not significant. This conclusion was likely to be a consequence of the chosen sites of experiment and of the genotypes.

MSW variation among the dwarf genotypes (0.289-0.462) was larger than that observed among tall indeterminate varieties $(0.230-0.350)$ (Huyghe, 1989), and the average MSW was higher than that of the determinate white lupin population $(0.151-0.374)$ studied by Julier et al (1995). The increase in the MSW of the dwarf population is a consequence of the choice of the tall progenitors. These were mainly Italian populations with a good frost tolerance and large seeds (Papineau, 1987). A high MSW increased both aerial and root growth during the winter (Huyghe, 1993) and consequently contributed to improve frost tolerance (Huyghe and Papineau, 1990). Among the highest yielding genotypes (ie, seed yield higher than $40 \mathrm{q} / \mathrm{ha}$ ), MSW ranged from 0.337 to $0.462 \mathrm{~g}$. The number of seeds $/ \mathrm{m}^{2}$ was the main yield component in the five sites 
studied. Nevertheless the high seed yield in Lusignan 1993 was achieved through high seed numbers and high MSW.

The mainstem plus first-order branches produced the major part of the seed yield as was also the case with other genotypes in other environments (Duthion et al, 1987; Herbert, 1979; Huyghe et al, 1994b; Julier et al, 1993; LopezBellido and Fuentes, 1990). The first-order branches yielded more than the other orders of branches. The same pattern has been observed for XA100 under other agronomic conditions (Harzic et al, 1995). The major part of seed yield was produced on the mainstem for the tall indeterminate cultivar Lunoble (Harzic et al, 1995; Huyghe et al, 1994b). Thus, compared to Lunoble, it seemed that dwarfism modified seedyield distribution within the different branch orders: the seed-yield contribution of the firstorder branches increased. The low mainstem seed yield of XA100 was associated with late pod and seed abortion (Harzic et al, 1995). This pattern was not observed for most of the F4 generation of the genotypes involved in the present study (Harzic, 1992).

The architectural traits had higher heritabilities than the seed yield $\left(h^{2} \geq 0.88\right)$. The same trend has been observed on other lupin populations (Le Sech and Huyghe, 1991; Julier et al, 1995). Genetic variation in flowering date, stem length or number of leaves was high. Variation in number of leaves of the first-order branches was associated with a variation in the flowering date. It has been demonstrated that the flowering date was positively linked to the number of leaves (ie, number of internodes) on the mainstem (Duthion et al, 1994). The genetic correlation between the flowering date and the mainstem height (ie, number of internodes*internode length) was not high $(r=0.27)$. As the relationship between the number of leaves and flowering date of the mainstem does not vary among genotypes (Huyghe, personal communication), the effect of dwarfism on internode length was likely to be varied among genotypes. The effect of dwarfism on internode length was also observed for the first-order branches.

In white lupins, relationships between characters related to plant architecture and growth, have been observed by McGibbon and Williams (1980) and Huyghe et al (1994b). McGibbon and Williams (1980) showed that at high density, a high number of branches for spring-type white lupins reduced seed yield because of a competition between vegetative and reproductive growth.
This was confirmed by Huyghe et al (1994b) who found that seed yield from the mainstem was negatively correlated to the total dry weight of the branches. In the present study, the genetic correlation between the number of first-order branches and seed yield was low (0.17). Julier et al (1995) found a genetic correlation of 0.66 between this architectural trait and the seed yield among determinate genotypes, in which the limited size of the first-order branches appeared as a limiting factor for light interception, biomass production and seed yield. The range of variability in the number of first-order branches was high in determinate genotypes $(0.03-9.43)$, but was not consequent in the present study.

Among the dwarf genotypes under study, the genetic correlation between seed yield and the flowering date was very low. Selection of high yielding genotypes would be possible in a wide range of flowering dates. The genetic correlation between mainstem height and seed yield was positive. This showed that vegetative development and growth must not be over-reduced. Mainstem height was also correlated to the number of leaves and branches, ie, the plant development, and to MSW. It has been shown that the number of leaf primordia during the vegetative stage of the main apex was linked to the MSW in tall indeterminate genotypes (Huyghe, 1993). Dwarfism did not modify this relationship (Huyghe, personal communication). Thus a large MSW, as characteristic of a genotype, contributed to the large vegetative development of the mainstem and consequently of the first-order branches (Huyghe et al, 1994a) of the plant that originated from the seed. Large vegetative development could also contribute to a better seed filling, within the dwarf genetic background. A similar relationship between stem height and seed yield was observed on dwarf wheat for which Gale and Law (1977) proposed to select tall dwarf to increase seed yield. The presence of dwarfing genes should prevent excessive vegetative development and provide a positive effect on plant yield, while minor genes variation could be exploited to select taller and higher-yielding genotypes.

The present study showed that the dwarf population was suitable for seed yield improvements. Moreover, dwarfism is a way of reducing plant height and of improving lodging resistance. Nevertheless, dwarfism does not reduce the duration of the growth cycle (Harzic et al, 1995), which is a constriction in the cultivation of the white lupin under cool and moist conditions (Julier et al, 1993). On the contrary, a determi- 
nate structure reduced the duration of the growth cycle (Julier et al, 1993) and thus secured maturity. The combination of dwarfism and a determinate structure (Julier et al, 1995) is a current breeding objective for autumn-sown white lupin. It aims at improving the lodging resistance of the determinate genotypes. The dwarf population of the present study could be a valuable source of dwarf progenitors to improve the determinate population.

\section{ACKNOWLEDGMENTS}

We wish to thank the Poitou-Charentes region for its financial support. The authors are grateful to JM Pissard and $P$ Cormenier for their efficient technical assistance in Lusignan, to $V$ Tortel for her data collecting in Gotheron and to J Raimbault for his technical assistance in Cossé-Le-Vivien. We are also grateful to A de Pourtalès for her corrections of English in the present version of the manuscript.

\section{REFERENCES}

Becker WA (1975) Manual of Quantitative Genetics, third edition. Washington State University

Duthion C, Amarger N, Mariotti A (1987) Accumulation potentielle de matière sèche et d'azote chez le lupin blanc de printemps. agronomie 7, 585-593

Duthion C, Ney B, Munier-Jolain NM (1994) Development and growth of white lupin: implications for crop management. Agron J 86, 1039-1045

Étévé G, Derieux M (1982) Variabilité de la durée de la phase végétative chez le pois (Pisum sativum $\mathrm{L}$ ). Application à la sélection de types résistants à l'hiver et à la détermination de la date de semis. agronomie 2, 813-817

Gale MD, Law CN (1977) Identification and exploitation of Norin 10 semidwarfing genes. Plant Breeding Inst Annu Rep 1976 (Cambridge, England), 21-35

Green AG, Oram RN, Read BJ (1977) Genetic variation for seed yield, protein content, oil content, and seed weight in Lupinus albus. Aust J Agric Res 28, 785-793

Harizc N (1992) Variabilité phénotypique et génotypique de l'architecture des lupins blancs nains d'hiver : conséquences sur l'interception du rayonnement et l'élaboration du rendement. Mémoire DEA, Ina Paris-Grignon, 52

Harzic N, Huyghe C (1996) Dwarfism does not modify mean area per leaf and light interception in indeter- minate autumn-sown white lupin. J Agric Sci 127 (in press)

Harzic N, Huyghe C, Papineau J (1995) Dry matter accumulation and seed yield in dwarf autumn-sown white lupin (Lupinus albus L). Can J Plant Sci 75, 549-555

Herbert ST (1979) Density studies on lupins. II. Components of seed yield. Ann Bot 43, 65-73

Huyghe C (1989) Discussion of selection criteria for grain yield in lupin breeding. Lupin production and bio-processing for feed, food and other by-products. Proceedings of the joint CEC-NCRD workshop, Israel, 21-30

Huyghe C (1993) Growth of white lupin seedlings during the rosette stage as affected by seed size. agronomie 13, 145-153

Huyghe C, Papineau J (1990) Winter development of autumn-sown white lupin. Agronomic and breeding consequences. agronomie 10, 709-716

Huyghe C, Harzic N, Julier B, Papineau J (1994a) Comparison of determinate and indeterminate autumn-sown white lupins under the western European climate. Proceedings of the First Australian lupin technical symposium. Perth, Australia, 123-128

Huyghe C, Julier B, Harzic N, Papineau J (1994b) Yield and yield components of indeterminate autumn-sown white lupin (Lupinus albus) cv Lunoble. Eur J Agron 3, 145-152

Julier B, Huyghe C, Papineau J, Milford GFJ, Day J, Billot C, Mangin C (1993) Yield and yield stability of determinate and indeterminate autumn-sown white lupin (Lupinus albus L) grown at different locations in France and the UK. $J$ Agric Sci 121, 177-186

Julier B, Huyghe C, Papineau J, Billot C, Deroo C (1995) Genetic and environmental variation in architecture and yield components in determinate white lupin (Lupinus albus L). Euphytica 81, 171-179

Le Sech L, Huyghe C (1991) Diallel analysis in white lupin. Breeding consequences. agronomie 11, 719726

Lopez Bellido L, Fuentes M (1990) Growth, yield and yield components of lupin cultivars. Agron $J 82$, 1050-1056

McGibbon R, Williams W (1980) Effects of plant and canopy density on seed yield and oil content in white lupin (Lupinus albus). Expl Agric 16, 409-414

Papineau J (1987) La résistance au froid des lupins blancs (Lupinus albus L). Variabilité génétique, sélection, création de matériel végétal doux. Mémoire Ensa, Montpellier, $81 \mathrm{p}$

SAS Institute (1988) SAS/STAT User's Guide, Release 6.03 Edition. SAS Institute Inc, Cary, NC, USA 